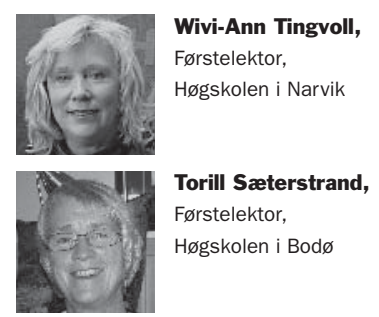

\title{
Sats på rehabilitering
}

\author{
Rehabilitering blir ikke prioritert verken i åpen omsorg eller i sykehjemmene.
}

\section{På grunn av et stort antall pleiepasienter og få korttidsplasser blir rehabiliteringsplanene skjøvet til side.}

\section{www.sykepleien.no}

\author{
Les mer og finn \\ litteraturhenvisninger på \\ www.sykepleien.no \\ Søkeord: \\ skilsmissebarn \\ samlivsbrudd \\ samtalegrupper \\ samtalebilder
}

Denne artikkelen bygger på en studie av viljen og evnen til gjennomføring av rehabilitering i kommunene. Hensikten med studien var å finne ut om innholdet i rehabiliteringstjenesten til eldre er i samsvar med definisjonen og kravet til rehabilitering i pleie og omsorgstjenesten i kommunene.

Ifølge Stortingsmelding nr. 21 (1) er helhetlig rehabilitering inndelt $\mathrm{i}$ ulike nivåer: Individ, gruppe og institusjonsnivå. Individnivået handler om den som er rammet av sykdom. Fokuset på dette nivået er å møte brukeren på hans/hennes nivå slik at brukerens egne krefter, evner og ønsker blir styrende for hele rehabiliteringsprosessen. Siden den enkeltes behov og ønsker er subjektive, bør denne prosessen være ulik når det gjelder utforming og innhold. Det andre nivået er gruppenivået. Det vil si at rehabilitering av for eksempel slagpasienter krever kompetanse fra flere faggrupper. Det tredje og siste nivået er institusjonsnivået. Den medisinske rehabilitering starter på sykehusene. De regionale helseforetakene skal etter forskrifter om rehabilitering, og lov om spesialisthelsetjeneste sørge for at innbyggeren tilbys nødvendig rehabilitering $(2,3)$. Deretter blir pasienten enten sendt til rehabiliteringsinstitusjon eller kommunen, ettersom hvor det er plass til ham for videre oppfølging. I denne prosessen kreves det et nært samarbeid, både med hensyn til kompetanse og ressurser, mellom sykehuset og kommunehelsetjenesten.

\section{Helhetstenkning}

Ifølge Stortingsmelding nr 8 (4) har revirtenkning og de enkelte profesjoners roller forhindret fagpersonell i å se hverandres arbeidsområder. Et vellykket rehabiliteringsarbeid forutsetter at de ulike faggruppene tar inn over seg hva helhetlig rehabilitering omfatter og at behovene og graden av assistanse vil variere fra person til person. Det hersker imidlertid uenighet og usikkerhet blant helsepersonell, og andre aktører som er involvert i rehabiliteringsprosessen, om hva som er sentralt i dette arbeidet og hvilke samarbeidsformer som er mest hensiktsmessig. I fagmiljøene er det forskjellige meninger om hva rehabilitering innbærer, hvilke funksjoner de ulike faggrupper skal ha, hvordan arbeidet skal organiseres og hvilken innsats som er nødvendig.

\section{Bruker i fokus}

Ifølge Normann, Sandvin \& Thommesen (5) har alle med nedsatt funksjonsevne behov for sammensatt og koordinert bistand uavhengig av alder, om den nedsatte funksjonsevnen er av psykisk, fysisk eller sosial art eller en kombinasjon av disse og om funksjonsproblemet er medfødt eller ervervet. Hensikten med rehabiliteringsvirksomheten er at brukeren skal få bistand til å kunne delta i samfunnet på egne premisser og på lik linje med andre. En bedret funksjon er ikke alltid målet, mestring $i$ rehabiliteringssammenheng handler om at brukeren får en opplevelse av å ha herredømme over egen situasjon. Informasjon er viktig ifølge Kjeken m.fl (6). De påpeker at jo bedre informert pasienten er om sin egen tilstand og sykdom desto større er sjansen for at de deltar i treningen.

Granbo \& Helbostads (7) påpeker i sine forskningsprosjekter i sykehjem i Norge at diagnostikk og tilbud må individualiseres, noe som skiller seg fra oppfatningen av sykehjemmets beboere som en homogen masse. Det pekes på at både sykehjem og hjemmebasert omsorg lider under manglende faglig kompetanse og ressurser, slik at hensynet til den enkelte ofte ikke blir ivaretatt.

USA-studiene til Leveille et al. (8) viser at økt kompetanse blant ansatte og tilrettelagte programmer om fysisk aktivitet fører til lavere frekvens av innleggelser i sykehus, en bedre hverdag og mindre bruk av beroligende medikamenter.

De refererte studiene viser at effekten av rehabilitering utvilsom er god og at det er behov for en sammensatt og koordinert bistand. Det gjelder både på individ-, gruppe- og institusjonsnivå.

\section{Metode}

Ettersom denne studien skulle omhandle hvordan det var lagt til rette for rehabilitering av eldre og hvilke utfordringer det var i oppfølgingen av rehabilitering i kommunene, valgte vi å intervjue totalt ti ledere i pleie- og omsorgstjenesten i Norge i 2006.

Analyseringen av datamaterialet er gjort i henhold til Kvales (5) innholdsanalyse som er inndelt $i$ tre faser; 1) selvforståelse, 2) kritisk forståelse basert på «common sence» og 3) teoretisk forståelse. Fortolkning av andre menneskers opplevelse av noe vil alltid innebære en utvelgelse. Det som velges ut av informantene selv er enten bevisst eller ubevisst; det som er betydningsfullt i øyeblikket eller som huskes i øyeblikket ved samtaler. Informantenes utsagn er allerede fortolket av dem selv, før de blir fortalt til intervjueren. På denne måten vil annen, og for noen kanskje like aktuell, informasjon tre i bakgrunnen. Når vi kodet intervjuene så vi etter data i intervjuene og fant fram til tema som så ble redusert ved å gruppere temaene. Intervjuene ble lest gjennom flere ganger av begge forskerne for å sikre mest mulig valid analyse. 


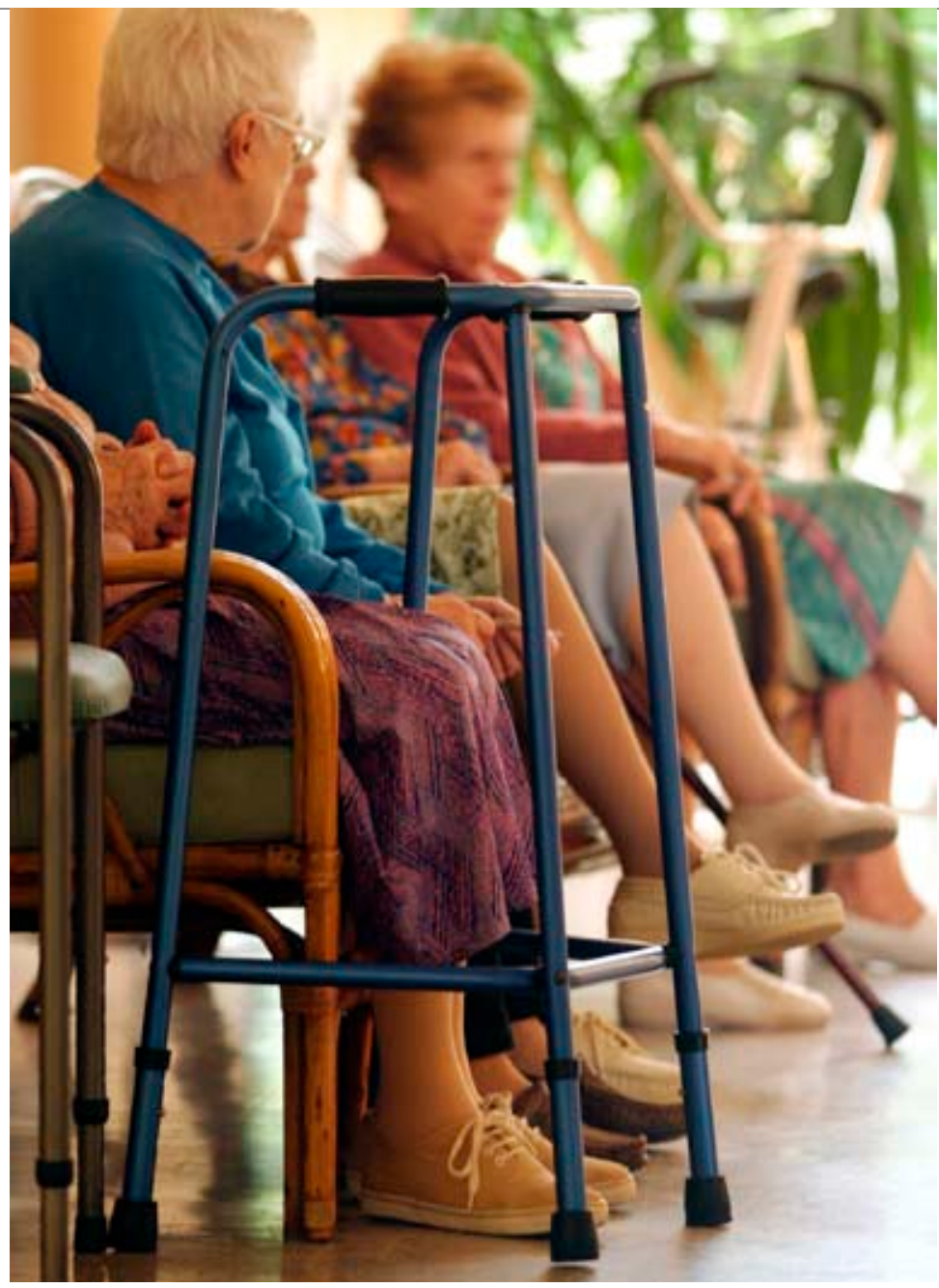

\section{Plassmange}

Studien viser at tjenesten er presset på grunn av utskrivningsklare pasienter fra sykehus, mangelfull tverrfaglig oppfølging og manglende samhandling. Presset fra sykehusenes side om å ta i mot utskrivningsklare pasienter skapte mange problemer på grunn av mangel på rehabiliteringsplasser. Flere hevdet at det var for få rehabiliterings- og kortidsplasser på sykehjemmene. Det kom frem at mange pasienter blir skrevet ut av sykehuset for tidlig og har behov for et rehabiliteringstilbud. De påpekte også at tidspresset er stort. Rehabilitering blir ikke prioritert verken $\mathrm{i}$ åpen omsorg eller i sykehjemmene. Stillinger for ergoterapeuter, aktivitører og fysioterapeuter var reduserte eller lagt ned. Det ble sagt at det heller ikke finnes konkrete handlingsplaner for fysisk og sosial aktivitet i tjenesten som sådan: «Vi prøver å spare små stillingsbrøker slik at vi får skrapt sammen nok penger til en halv stilling som aktivitør. Tidligere hadde vi tre stillinger innenfor rehabilitering, og nå har vi en igjen, vi vil kreve å få beholde stillingen. Men økonomien er dårlig.» i hjemmebasert omsorg eller på sykehjemmene. De ansatte fikk heller ingen direkte veiledning i hvordan de kunne trene opp pasientene.

I enkelte kommuner hadde sykepleielederne dårlig erfaring med

STORT BEHOV: Mange pasienter bli skrevet ut av sykehuset for tidlig og har behov for rehabiliteringstilbud.

Illustrasjonsfoto: Colourbox.com

rehabiliteringstjenesten. De hevdet at ansatte i denne delen av tjenesten hadde en tendens til å sitte på kontor og skrive vedtak. I noen av kommunene kom det fram at de er klar over behovet for rehabilitering og at rehabiliteringsplaner er politisk vedtatt, men likevel skjer det lite. Rehabiliteringstilbudet er ennå ikke kommet på plass: «Det skal starte opp et rehabiliteringsteam til neste år, men vi er spente på hva det betyr i praksis!» På grunn av et stort antall pleiepasienter og få korttidsplasser blir rehabiliteringsplanene skjøvet til side.

\section{Diskusjon}

Funnene i denne studien viser at rehabiliteringen var lavt prioritert i de ti kommunene.

Utskrivningsklare pasienter fra sykehuset øver et stort press på kommunene. Kommunene sitter med et totalansvar og ofte vil spesialisthelsetjenesten være premissleverandør for hvor skillet mellom spesialisthelsetjenesten og kommunenes ansvar går.

Pasienter skal ha et rehabiliteringstilbud i kommunen når de utskrives fra sykehuset. Dette kan få stor betydning for pasienten som blir liggende i sykehuset i påvente av tilbud fra kommunen. Når de utskrivningsklare pasientene kommer ut til kommunehelsetjenesten, så finnes det heller ikke der et godt nok tilbud. Ifølge Garåsen \& Johnsen (9) må samhandlingsarenaene mellom sykehus og primærhelsetjeneste styrkes som følge av presset av utskrivningsklare pasienter. For å kunne lykkes med dette er det nødvendig å styrke tilbudene i kommunehelsetjenesten, opprette kortids- og rehabiliteringsplasser i sykehjem og sørge for at rehabiliteringstilbudene er av høy faglig standard.

Rehabilitering krever faglig bredde med ulik kompetanse. Ansettelse av tverrfaglig personell i omsorgstjenesten vil ha stor betydning for å få til en helhetlig rehabilitering. Rehabilitering i tilstrekkelig omfang og til rett tid, kan være en forutsetning for å redusere den enkeltes hjelpebehov og dermed øke livskvaliteten for den det gjelder.

\section{Konklusjon}

Sykepleielederne mener kommunehelsetjenesten må prioritere rehabilitering. Mange utskrivingsklare sykehuspasienter har krav på et rehabiliteringstilbud $\mathrm{i}$ henhold til kommunehelsetjenesteloven. Mangel på fagpersonell har betydning for innføring av individuell plan. Samtidig er det viktig å øke kompetansen og arbeide med holdningsendring. Undersøkelsen viser at rehabilitering må forankeres både på individnivå med tilbud om individuell plan, gruppenivå med riktig kompetanse ut fra behovet for rehabilitering og på institusjonsnivå med tilbud om en rehabiliteringsplass på sykehjem i kommunen eller annen rehabiliteringsinstitusjon. Fremtidig satsning på rehabilitering i kommunehelsetjenesten har stor betydning for et godt kvalitetsmessig tilbud til de kroniske syke.

\footnotetext{
LITTERATUR

1. Stortingsmelding $\mathrm{nr} 21$ (1998-99):Ansvar og meistring. Mot ein heilskapele rehabiliteringspolitikk. Oslo: Sosial og helsedepartementet.

2. Forskrifter om habilitering og rehabilitering (2001). Oslo: Sosial og helsedepartementet.

3. Lov av 1. januar $2001 \mathrm{nr} .61$ Spesialisthelsetjenesten med mer. Oslo: Lovdata. Sosial og helsedept. 2001

4. Stortingsmelding nr 8 (1998-99). Hand lingsplan for funksjonshemmet 1998-2001. delaktighet og deltakelse. Oslo: Sosial og helsedepartementet.

5. Kvale, S. Kvalitative forskningsintervju. Oslo: Universitetsforlaget, 2007.

6. Kjeken I, Dagfinrud H, Mowinckel P, Kvien TK, Finset A. Rheumatology Care:involment in medical decisions received information, satisfaction with care, and unmet health care needs in patiens with rheumatoid arthritis and ankylosing spondyøitis. 2006;55 (3) 394-401.

7. Granbo Helbostad J. Hvordan ivareta sykehjemsbeboernes behov for bevegelse? Tidsskr Nor Legeforen 2006; 15(126): 1934-6.

8. Leveille SG, Wagner EH, Davis C, et al. Preventing disability and managing chronic ill16ness in frail older adults: a randomized trial of a community-based partnership with primary care. J Am Geriatr Soc 1998 ; 46:1191-8.

9. Garåsen $\mathrm{H}$, Johnsen. R Samarbeid mellom kommune og spesialisthelsetjeneste - erfaringer fra Trondheim. Tidsskr Nor Lægeforen 2005; 125: 1198-200.
} 